Sains Malaysiana 48(1)(2019): 93-102

http://dx.doi.org/10.17576/jsm-2019-4801-11

\title{
Optimization of the Production of Lovastatin from Aspergillus sclerotiorum PSU- RSPG178 under Static Liquid Culture using Response Surface Methodology
}

(Pengoptimuman Pengeluaran Lovastatin daripada Aspergillus sclerotiorum PSU-RSPG178 di bawah Kultur Cecair Statik menggunakan Kaedah Gerak Balas Permukaan)

\author{
SUDARAT SUWANNARAT, JUTARUT IEWKITTAYAKORN, YAOWAPA SUKPONDMA, VATCHARIN RUKACHAISIRIKUL, \\ SOUWALAK PHONGPAICHIT \& WILAIWAN CHOTIGEAT*
}

\begin{abstract}
The effect of lovastatin on cholesterol synthesis is well known. Although lovastatin has been produced from several Aspergillus species and cultivation systems, the yield of lovastatin from Aspergillus sclerotiorum PSU-RSPG 178 in a static liquid system has not yet been determined. Therefore, the objective of this study was to optimize lovastatin production from this strain using a central composite design developed through response surface methodology (RSM). The inoculum was prepared from mycelium or spore cultured in static liquid and shaking systems with potato dextrose broth (PDB) as the medium. The best inoculum preparation and cultivation systems were selected to study the optimization of the four fermentation parameters of medium concentration $(X-5 X)$, temperature $\left(25-37^{\circ} \mathrm{C}\right)$, culture medium to flask volume ratio (2.5-12.5) and time (7-35 days). The best inoculum preparation was the mycelium method and the best cultivation system was the static liquid system. In the optimization procedure, a yield of $1315.69 \mathrm{mg} / \mathrm{L}$ lovastatin was obtained at a PDB concentration of $5 X$, a temperature of $25^{\circ} \mathrm{C}$, a medium to flask volume ratio of $1: 2.5$ and a time of 21 days. In a model employing the optimized parameters, temperature was found to have the most effect on lovastatin production, which will decrease if temperature increases above $25^{\circ} \mathrm{C}$. Based on this study, A. sclerotiorum PSU-RSPG178 can be a useful strain for producing lovastatin and RSM as an optimization technique not only reduced the number of experiments but also resulted in an optimized lovastatin yield.
\end{abstract}

Keywords: Aspergillus sclerotiorum PSU-RSPG178; hypercholesterolemic; liquid static culture; lovastatin; RSM

\section{ABSTRAK}

Kesan lovastatin pada sintesis kolesterol telah diketahui. Walaupun lovastatin dihasilkan daripada beberapa spesies Aspergillus dan sistem penanaman, hasil bagi lovastatin daripada Aspergillus sclerotiorum PSU-RSPG178 dalam sistem cecair statik masih belum ditentukan. Oleh itu, objektifkajian ini adalah untuk mengoptimumkan pengeluaran lovastatin daripada strain ini menggunakan reka bentuk komposit pusat yang dibangunkan melalui kaedah gerak balas permukaan (RSM). Inokulum disediakan daripada miselium atau spora dikultur dalam cecair statik dan sistem goncangan dengan kaldu kentang dektrosa (PDB) sebagai medium. Sistem penyediaan dan penanaman inokulum terbaik telah dipilih untuk kajian pengoptimuman empat parameter penapaian kepekatan sederhana $(X-5 X)$, suhu $\left(25-37^{\circ} \mathrm{C}\right)$, kultur medium kepada nisbah isi padu kelalang (2.5-12.5) dan masa (7-35 hari). Persediaan inokulum terbaik adalah kaedah miselium dan sistem penanaman terbaik adalah sistem cecair statik. Dalam prosedur pengoptimuman, hasil lovastatin sebanyak $1315.69 \mathrm{mg} / \mathrm{L}$ telah diperoleh pada kepekatan $P D B 5 X$, suhu $25^{\circ} \mathrm{C}$, medium kepada nisbah isi padu kelalang 1:2.5 dan tempoh masa 21 hari. Model yang menggunakan parameter optimum, suhu didapati memberi kesan ketara pada pengeluaran lovastatin, yang akan berkurang jika suhu meningkat melebihi $25^{\circ} \mathrm{C}$. Berdasarkan kajian ini, A. sclerotiorum PSU-RSPG178 boleh menjadi strain yang berguna untuk menghasilkan lovastatin dan RSM sebagai teknik pengoptimuman yang bukan sahaja mengurangkan bilangan uji kaji tetapi juga memberikan hasil optimum lovastatin.

Kata kunci: Aspergillus sclerotiorum PSU-RSPG178; hiperkolesterol; kultur cecair statik; lovastatin; RSM

\section{INTRODUCTION}

Most heart attacks and cardiovascular diseases are the result of hypercholesterolemia which is the accumulation of cholesterol in blood plasma and leads to atherosclerosis. To reduce levels of cholesterol (>200 mg/dL) in the blood, lovastatin (mevinolin and monacolin $\mathrm{K}$ ) has been proposed as a potent hypercholesterolemic agent. Lovastatin is an inhibitor of 3-hydroxy-3-methylglutaryl-CoA reductase
(HMG-CoA reductase), which is a rate-limiting enzyme in cholesterol biosynthesis (Lai et al. 2005). It is a member of a family of drugs generally called statins which are in clinical use for reducing LDL levels and are more widely used than other cholesterol-lowering drugs. Lovastatin not only plays a role in the enhancement of endothelial function, but also has anti-inflammatory and antiatherothrombotic properties and also plays a key role as 
an immunomodulator (Mihos et al. 2014) and a cancer cell apoptosis agent (Zhao et al. 2016).

Lovastatin is produced as a secondary metabolite of the polyketide pathway by various fungi such as Monascus spp., Beauveria bassiana, Aspergillus fumigates and Aspergillus terreus (Mukhtar et al. 2014). Among the various lovastatin producing species, $A$. terreus is well known as the most productive (Marcin \& Marta 2011; Samiee et al. 2003) and can be grown under submerged fermentation $(\mathrm{SmF})$ or solid state fermentation (SSF) (Kamath et al. 2015; Mulder et al. 2015). Grown under submerged cultivation in soluble starch and sodium glutamate as, respectively, the carbon and nitrogen sources, the lovastatin production from $A$. terreus LA414 was $523.9 \mathrm{mg} / \mathrm{L}$ after cultivation for 8 days at a temperature of $28^{\circ} \mathrm{C}$ (Jia et al. 2009). A. terreus ATCC 20542, cultured in a lactose-based medium (LBM) at $28^{\circ} \mathrm{C}$ and shaken at $200 \mathrm{rpm}$, yielded $873 \mathrm{mg} / \mathrm{L}$ on day 10 (Lai et al. 2007), while A.terreus ATCC 20542, cultured in a mixture of glycerol and lactose under solid state fermentation at $30^{\circ} \mathrm{C}$, yielded $122 \mathrm{mg} / \mathrm{L}$ on day 7 (Marcin et al. 2011). Among cultivation systems, SmF was found to be the most appropriate for culturing fungi for lovastatin production in batch and fed-batch systems (Mulder et al. 2015). However, it was noted that SmF relies on the use of shaking which results in a high cost culture system. There is, therefore, reason to investigate other culture systems which can produce high yields of lovastatin more economically. Normally, fungi are able to grow without a shaking system and often grow on plant matter. Static liquid culture has been successfully employed to cultivate various plants such as rhododendron (Douglas et al. 1984), roses (Wong \& Chu 1995), garlic (Kim et al. 2003) and Doritaenopsis (Tsai \& Chu 2008), suggesting that applying $\mathrm{SmF}$ in a static liquid culture, as an alternative to a shaking system, may be of interest in culturing fungi to produce lovastatin. Moreover, the cultivation of fungi to produce lovastatin using a static liquid culture has not previously been investigated.

Studies seeking to develop and enhance lovastatin production have mainly focused on finding new strains of source fungi and the optimization of fermentation parameters such as temperature, humidity, time and aeration (Dikshit \& Tallapragada 2015). In the case of secondary metabolite production, the type of inoculum, either from fungi or hyphae, is also very important (Samiee et al. 2003). The optimization of each parameter requires a number of experiments and is time consuming because each factor can only be optimized by keeping the other factors constant and the fact that the optimum constant levels may be unknown could produce inferior results because of the combined effect of all the factors. However, these limitations can be overcome by optimizing all the parameters of interest using response surface methodology (RSM) (Pansuriya \& Singhal 2010) RSM is applied to experimental design to find the optimum conditions and reduce process variability. It can also reduce the time and number of experiments needed to determine reliable optimum levels. Moreover, the relative significance of each parameter can be evaluated by this method (Zhou et al. 2009). Suraiya et al. (2018) applied RSM method to optimize fermentation parameters on lovastatin production by Monascus purpureus using Saccharina japonica as solid fermented substrate. The experiments in which lovastatin was produced under optimal conditions yielding $13.98 \mathrm{mg} / \mathrm{g}$ dry fermented substrate corresponding to that of predicted combination of process parameters yielding $13.40 \mathrm{mg} / \mathrm{g}$ dry fermented substrate. Atlı et al. (2016) optimized the culture conditions to improve lovastatin production from Omphalotus olearius OBCC 2002 using RSM. A medium containing glucose $(10 \mathrm{~g} / \mathrm{L})$, peptone $(5 \mathrm{~g} / \mathrm{L})$, thiamine $(1 \mathrm{mg} / \mathrm{L})$, and $\mathrm{NaCl}(0.4 \mathrm{~g} / \mathrm{L})$ yielded $12.51 \mathrm{mg} / \mathrm{L}$ lovastatin under submerged fermentation. This yield was eight times higher than that produced using unoptimized media. Samiee et al. (2003) screened various filamentous fungi to study lovastatin production using the spore inoculum method. All the experiments were incubated in a complex medium in a rotary shaker incubator at $180 \mathrm{rpm}$ at $28^{\circ} \mathrm{C}$ for 7 days. The fungi used in the study, with their yields, were as follows: $A$. terreus $(55 \mathrm{mg} / \mathrm{L})$, A. parasiticus $(4.5 \mathrm{mg} / \mathrm{L})$, A. fischeri $(2.0 \mathrm{mg} / \mathrm{L}), A$. flavus $(9.0 \mathrm{mg} / \mathrm{L})$, A. umbrosus $(14.1 \mathrm{mg} / \mathrm{L})$, Penicillium funiculosom (pinophilum)(19.3 mg/L), Trichoderma viridae $(9.0 \mathrm{mg} / \mathrm{L})$, Trichoderma longibrachiatum $(1.0$ $\mathrm{mg} / \mathrm{L})$, Acremonium chrysogenum $(2.5 \mathrm{mg} / \mathrm{L})$. Mouafi et al. (2016) reported that the optimal lovastatin production (3.353 mg/g of dried fermented matter) from A. fumigatus was achieved at a temperature of $\sim 28^{\circ} \mathrm{C}$ and a pH5.0 with an incubation period of 12 days. Elsewhere, the optimal yield of lovastatin from Monascus ruber, incubated at $25^{\circ} \mathrm{C}$, at $\mathrm{pH} 5.0$ under submerged fermentation with shaking at $150 \mathrm{rpm}$ for 10 days, was $131 \mathrm{mg} / \mathrm{L}$ (Sripalakit et al. 2011).

The optimum conditions for lovastatin production from the new strain, A. sclerotiorum PSU-RSPG 178, isolated from a soil sample, were still unexplored and the strain may be another source of lovastatin production. Phainuphong et al. (2016) indicated that the lovastatin produced from $A$. sclerotiorum RSPG 178 displayed much stronger noncytotoxic effects against noncancerous Vero cells activity, with an $\mathrm{IC}_{50}$ value of $2.2 \mu \mathrm{M}$.

The main objective of this research was thus to optimize lovastatin production from $A$. sclerotiorum PSURSPG 178 using a central composite design employing RSM. We used a strain of A. sclerotiorum PSU-RSPG 178 cultured from mycelium and spore inoculum cultured under static liquid and shaking systems with potato dextrose broth (PDB) as the medium. To determine the best conditions of the fermentation parameters for optimization, we evaluated medium concentration (X$5 \mathrm{X})$, temperature $\left(25-37^{\circ} \mathrm{C}\right)$, medium to flask volume ratio (2.5-12.5 by volume) and time (7-35 days). The lovastatin yields were analyzed in both cell and broth extracts. 


\section{MATERIALS AND METHODS}

\section{MICROORGANISMS}

The soil fungus strain, A. sclerotiorum PSU-RSPG178 was isolated from a soil sample collected from the Plant Genetic Conservation Project under the Royal Initiation of Her Royal Highness Princess Maha Chakri Sirindhorn at Ratchaprapa Dam in Suratthani Province, Thailand. The $A$. sclerotiorum PSU-RSPG178 was grown on potato dextrose agar (PDA) at $28^{\circ} \mathrm{C}$ for 7 days to prepare the inoculum.

\section{CULTIVATION SYSTEM}

The $A$. sclerotiorum PSU-RSPG178 inoculum was prepared as follows: Mycelial plug: The mycelial plug inoculum was prepared according to Daengrot et al. (2015). Five mycelial agar plugs $\left(0.5 \times 0.5 \mathrm{~cm}^{2}\right)$ were inoculated into $250 \mathrm{~mL}$ Erlenmeyer flasks containing $100 \mathrm{~mL}$ of PDB.

Spore suspension: The spore inoculum was prepared according to López et al. (2003). The spores were collected by washing the petri dish culture with a sterile aqueous solution of $2 \%$ Tween 20 in $0.85 \% \mathrm{NaCl}$ which was shaken for $30 \mathrm{~min}$ and diluted to a concentration of $2 \times 10^{8}$ spores/ $\mathrm{mL}$. Spores were counted with a hemocytometer. An aliquot of $500 \mathrm{~mL}$ of the spore suspension was inoculated into $250 \mathrm{~mL}$ Erlenmeyer flasks containing $100 \mathrm{~mL}$ of PDB. All experiments were cultured in a $150 \mathrm{rpm}$ shaking incubator at $28^{\circ} \mathrm{C}$ for 7,14 and 28 days. The method which gave the highest yield of lovastatin concentration was employed to prepare an inoculum of $A$. sclerotiorum PSU-RSPG178 for the study of cultivation systems. Two cultivation systems were tested; one used shaking (150 rpm), whereas the other was a static liquid system. Both systems were conducted at $28^{\circ} \mathrm{C}$ for 7,14 and 28 days.

\section{RSM EXPERIMENTAL DESIGN}

Development of the experiment to select the optimal fermentation parameters for lovastatin production employed a central composite design at five levels of RSM, created using the DESIGN EXPERT software 6.0.10 trial version (StatEase, Minneapolis, USA). The parameters included various concentrations of PDB, cultivation times, temperatures and ratios of medium to flask volume. The codes and actual factor levels at coded factor levels are shown in Table 1.
Based on the factor levels shown in Table 1, a set of 28 experiments was required with each variable being tested at five levels $(\mathrm{a}=2)$, as shown in Table 2. The inoculum was prepared according to previous experiments in 500 $\mathrm{mL}$ Erlenmeyer flasks and performed in triplicate.

The relationship between the coded and actual values, the independent variables and the responses were calculated according to the second order quadratic model shown in (1). The relative effects of two variables on response were investigated from three dimensional plots. The statistical parameters were analyzed using analysis of variance (ANOVA) with a significance level of $p<0.05$ (Dikshit \& Tallapragada 2015).

$$
\begin{aligned}
\text { Response }= & b_{0}+b_{1} X_{1}+b_{2} X_{2}+b_{3} X_{3}+b_{4} X_{4}+ \\
& b_{5} X_{1} X_{1}+b_{6} X_{2} X_{2}+b_{7} X_{3} X_{3}+b_{8} X_{4} X_{4}+ \\
& b_{9} X_{1} X_{2}+b_{10} X_{1} X_{3}+b_{11} X_{1} X_{4}+b_{12} X_{2} X_{3}+ \\
& b_{13} X_{2} X_{4}+b_{14} X_{3} X_{4}
\end{aligned}
$$

where Response is the response of the second order quadratic model (lovastatin yield); $b_{i}(i=0-14)$ are the regression coefficients; and $\mathrm{X}_{1}, \mathrm{X}_{2} \mathrm{X}_{3}$ and $\mathrm{X}_{4}$ are the coded independent factors.

\section{EXTRACTION OF LOVASTATIN}

The lovastatin was extracted from each sample according to Daengrot et al. (2015) and Phainuphong et al. (2016). In each case, the culture was filtered to separate the liquid and wet mycelia. The liquid was extracted twice with ethyl acetate $($ EtOAc) $(2 \times 100 \mathrm{~mL})$. The organic layer was evaporated over anhydrous $\mathrm{Na}_{2} \mathrm{SO}_{4}$ under reduced pressure until a dark brown gum was observed. The mycelia cakes were extracted with methanol $(500 \mathrm{~mL})$ and the methanol layer was concentrated under reduced pressure. Then, distilled water $(50 \mathrm{~mL})$ was added to the methanol extract and the mixture was washed twice with hexane $(2 \times 100 \mathrm{~mL})$. The hexane layer was evaporated over anhydrous $\mathrm{Na}_{2} \mathrm{SO}_{4}$ under reduced pressure to obtain a crude extract in the form of a dark brown gum. The aqueous residue was extracted twice with an equal amount of EtOAc. The EtOAc layer was dried over anhydrous $\mathrm{Na}_{2} \mathrm{SO}_{4}$.

TABLE 1 . Four variables in coded and natural units

\begin{tabular}{lcccccc}
\hline \multirow{2}{*}{ Variable with designate } & Code & \multicolumn{5}{c}{ Actual factor level at coded factor levels } \\
\cline { 3 - 7 } & & -1 & -0.5 & 0 & 0.5 & 1 \\
\hline PDB concentration (X PDB) & $\mathrm{X}_{1}$ & 1 & 2 & 3 & 4 & 5 \\
Time (days) & $\mathrm{X}_{2}$ & 7 & 14 & 21 & 28 & 35 \\
Medium to flask volume ratio & $\mathrm{X}_{3}$ & 2.5 & 5 & 7.5 & 10 & 12.5 \\
Temperature $\left({ }^{\circ} \mathrm{C}\right)$ & $\mathrm{X}_{4}$ & 25 & 28 & 31 & 34 & 37 \\
\hline
\end{tabular}




\section{HPLC ANALYSIS}

The sample was transferred to a micro-centrifuge tube and dissolved in $1.0 \mathrm{~mL}$ of acetonitrile (RCL Labscan, HPLC grade). Standard solutions used for calibration purposes were prepared in the same way as described for the sample solutions, containing 10,20,40,80,160, 320 and 640 ppm. Quantitative HPLC analyses were performed on an Agilent 1200 series DAD HPLC system using an ACE ( Generix $5 \mathrm{C} 18$ column $(250 \mathrm{~mm} \times 4.6 \mathrm{~mm} \times 5 \mathrm{~mm}$ i.d. $)$ with particles equilibrated at $25^{\circ} \mathrm{C}$. Acetonitrile was used as mobile phase $\mathrm{A}$, and mobile phase $\mathrm{B}$ was aqueous 0.1 $\% \mathrm{H}_{3} \mathrm{PO}_{4}(\mathrm{aq})$ (Fisher Scientific). The flow rate was $1 \mathrm{~mL} /$ min, the injection volume $20 \mathrm{uL}$ and peak detection was at $238 \mathrm{~nm}$. Analysis started with $60 \% \mathrm{~A}$ and $40 \% \mathrm{~B}$ for 20 min (Ruchir \& Rekha 2009).

\section{RESULTS AND DISCUSSION}

\section{OPTIMUM INOCULUM PREPARATION}

The yields of lovastatin produced using a mycelial plug inoculum preparation cultivated at $28^{\circ} \mathrm{C}$ for 7,14 and 21 days were $48.17 \pm 0.24,155.71 \pm 0.42$, and $36.18 \pm 0.57$ $\mathrm{mg} / \mathrm{L}$, respectively. Spore suspension inoculum yielded less than $1 \mathrm{mg} / \mathrm{L}$ of lovastatin in all the experiments. Thus, the optimum inoculum preparation system used for further study was the mycelial plug method.

\section{CULTIVATION SYSTEM}

After cultivation, a well grown mycelial film covered the surface of the cultivation medium in the static liquid system, while spherical pellets were present in the cultivation medium of the shaking system. It was noted that the cultivation system affects the morphological characteristics of the fungal hyphae/mycelia which is in accordance with the findings of Ibrahim et al. (2015). The lovastatin concentrations produced in both systems are shown in Figure 1 as a function of cultivation time. The $A$. sclerotiorum cultured under shaking for 14 days yielded $155.71 \pm 0.42 \mathrm{mg} / \mathrm{L}$ lovastatin which was more than that produced in a cultivation time of either 7 days $(48.17 \pm 0.24 \mathrm{mg} / \mathrm{L})$ or 21 days $(36.18 \pm 0.57 \mathrm{mg} / \mathrm{L})$. The yield of lovastatin from the static liquid system after 14 days was $149.85 \pm 3.54 \mathrm{mg} / \mathrm{L}$, which was higher than that produced after a cultivation time of either 21 days $(145.01 \pm 9.43 \mathrm{mg} / \mathrm{L})$ or 7 days $(79.57 \pm 0.24 \mathrm{mg} / \mathrm{L})$. These results indicated that 14 days was the optimum cultivation time for both cultivation systems. There was no significant difference $(p<0.05)$ between the lovastatin yield from the shaking system and the yield from the static system. The authors selected the static liquid culture system for further study since this system has the advantage of being easily monitored as well as more economical.

In addition, by the $7^{\text {th }}$ day of incubation, the PDB in both cultures had become more viscous. This increased viscosity rendered the cultures static and at this stage the fungal cells increased the synthesis of lovastatin until the $14^{\text {th }}$ day of incubation. The amount of lovastatin obtained from static liquid culture for 21 days was similar to that obtained at 14 days. In contrast, the amount of lovastatin obtained from shaking culture was clearly lower at 21 days than after 14 days. Cultivation for more than 14 days increases the viscosity of the PDB beyond the point where the cells are able to use the medium and the depletion of nutrients due to the longer culture period resulted in a lower yield of lovastatin. In addition, viscosity greatly impedes the oxygen transfer necessary for lovastatin production, as demonstrated in studies of $A$. terreus in which lovastatin production under the static condition gave a higher yield than under the shaking condition (Lai et al. 2005).

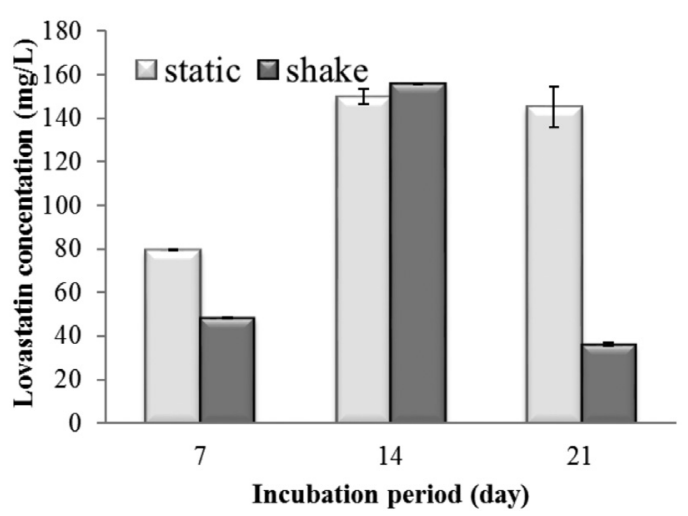

FIGURE 1. Lovastatin produced by A. sclerotiorum PSURSPG178 in a culture under shaking and static liquid culture as a function of cultivation time

\section{FERMENTATION PARAMETER OPTIMIZATION BY RSM}

The experimental results from the central composite design are shown in Table 2. The quadratic polynomial explaining the relationship of the four variables contributing to the lovastatin yield (equation (1)), can be rewritten as equation (2) after applying the regression analysis:

$$
\begin{aligned}
\begin{array}{l}
\text { Lovastatin yield }= \\
(\mathrm{mg} / \mathrm{l})
\end{array} & 12059.7+(533.97) \mathrm{X}_{1}+ \\
& (-42.12) \mathrm{X}_{2}+(-144.87) \mathrm{X}_{3}+ \\
& (-713.49) \mathrm{X}_{4}+11.69 \mathrm{X}_{1} \mathrm{X}_{1}+ \\
& 0.25 \mathrm{X}_{2} \mathrm{X}_{2}+1.61 \mathrm{X}_{3} \mathrm{X}_{3} \\
& 10.55 \mathrm{X}_{4} \mathrm{X}_{4}+(-1.30) \mathrm{X}_{1} \mathrm{X}_{2}+ \\
& (-0.80) \mathrm{X}_{1} \mathrm{X}_{3}+(-17.30) \mathrm{X}_{1} \mathrm{X}_{4}+ \\
& (-0.82) \mathrm{X}_{2} \mathrm{X}_{3}+1.27 \mathrm{X}_{2} \mathrm{X}_{4}+ \\
& 4.27 \mathrm{X}_{3} \mathrm{X}_{4}
\end{aligned}
$$

where $\mathrm{X}_{1}, \mathrm{X}_{2}, \mathrm{X}_{3}$ and $\mathrm{X}_{4}$ are the PDB concentration ( $\mathrm{X}$ PDB), the time (days), the medium to flask volume ratio and the temperature $\left({ }^{\circ} \mathrm{C}\right)$, respectively.

The result of an ANOVA on the quadratic model showed the model's F-value to be 14.86 (Table 3). The model's $\mathrm{P}$-value $(\mathrm{Prob}>\mathrm{F})$ is very low. This result indicates that the model is significant. Also the $\mathrm{R}^{2}$ (determination coefficient) value for the lovastatin yield was 0.974 indicating that $97.40 \%$ of the total variation in the experimental data could 
TABLE 2. Full factorial central composite design of four variables in coded and natural units along with the observed response

\begin{tabular}{|c|c|c|c|c|c|c|c|c|}
\hline \multirow{2}{*}{$\begin{array}{c}\text { Exp } \\
\#\end{array}$} & \multirow{2}{*}{$\begin{array}{c}\text { PDB } \\
\text { (X PDB) } \\
X_{1} \\
\end{array}$} & \multirow{2}{*}{$\begin{array}{c}\begin{array}{c}\text { Time } \\
\text { (days) }\end{array} \\
\mathrm{X}_{2} \\
\end{array}$} & \multirow{2}{*}{$\begin{array}{c}\text { Media to flask } \\
\text { volume ratio } \\
\text { (by volume) }\end{array}$} & \multirow{2}{*}{$\begin{array}{c}\text { Temp } \\
\left({ }^{\circ} \mathrm{C}\right)\end{array}$} & \multicolumn{4}{|c|}{ Lovastatin (mg/L) } \\
\hline & & & & & $\mathrm{BE}$ & $\mathrm{CE}$ & $\mathrm{CH}$ & Total \\
\hline 1 & 3 & 21 & 7.5 & 31 & $1.67 \pm 0.06$ & $1.18 \pm 0.41$ & $0.5 \pm 0.19$ & $3.65 \pm 0.05$ \\
\hline 2 & 4 & 14 & 10 & 28 & $69.02 \pm 15.58$ & $346.44 \pm 89.28$ & $45.87 \pm 14.32$ & $461.32 \pm 111.88$ \\
\hline 3 & 3 & 21 & 7.5 & 37 & $<0.001$ & $<0.001$ & $<0.001$ & $<0.001$ \\
\hline 4 & 4 & 28 & 10 & 28 & $62.56 \pm 3.67$ & $148.87 \pm 53.79$ & $9.48 \pm 4.57$ & $218.50 \pm 60$ \\
\hline 5 & 2 & 14 & 5 & 28 & $69.76 \pm 6.51$ & $177.32 \pm 18.62$ & $31.38 \pm 16.18$ & $278.47 \pm 23.91$ \\
\hline 6 & 4 & 14 & 5 & 28 & $113.41 \pm 72.73$ & $241.36 \pm 82.18$ & $175.82 \pm 46.78$ & $496.70 \pm 41.90$ \\
\hline 7 & 3 & 21 & 2.5 & 31 & $0.27 \pm 0.12$ & $0.53 \pm 0.32$ & $0.19 \pm 0.13$ & $0.99 \pm 0.5$ \\
\hline 8 & 3 & 21 & 12.5 & 31 & $4.32 \pm 0.61$ & $1.32 \pm 0.25$ & $1.34 \pm 0.32$ & $6.12 \pm 1.95$ \\
\hline 9 & 3 & 21 & 7.5 & 25 & $42.97 \pm 1.9$ & $566.71 \pm 42.65$ & $77.04 \pm 10.85$ & $686.72 \pm 66.71$ \\
\hline 10 & 3 & 21 & 7.5 & 31 & $1.51 \pm 0.1$ & $1.55 \pm 0.59$ & $0.41 \pm 0.04$ & $3.47 \pm 0.69$ \\
\hline 11 & 2 & 7 & 7.5 & 28 & $22.50 \pm 5.33$ & $127.97 \pm 49.37$ & $9.63 \pm 2.18$ & $160.09 \pm 55.48$ \\
\hline 12 & 5 & 21 & 7.5 & 31 & $0.73 \pm 0.29$ & $2.73 \pm 1.29$ & $0.95 \pm 0.08$ & $4.41 \pm 1.54$ \\
\hline 13 & 3 & 35 & 7.5 & 31 & $6.37 \pm 2.73$ & $6.42 \pm 3.31$ & $11.85 \pm 3.54$ & $24.65 \pm 10.04$ \\
\hline 14 & 2 & 28 & 10 & 28 & $35.85 \pm 0.62$ & $43.61 \pm 1.13$ & $15.12 \pm 2.83$ & $94.58 \pm 18.46$ \\
\hline 15 & 4 & 28 & 5 & 34 & $0.69 \pm 0.43$ & $0.25 \pm 0.18$ & $0.68 \pm 0.44$ & $0.83 \pm 0.59$ \\
\hline 16 & 2 & 14 & 10 & 34 & $0.44 \pm 0.26$ & $0.44 \pm 0.16$ & $0.61 \pm 0.57$ & $1.49 \pm 0.99$ \\
\hline 17 & 2 & 28 & 5 & 34 & $0.76 \pm \pm 0.08$ & $0.19 \pm 0.11$ & $0.41 \pm 0.36$ & $1.01 \pm 0.58$ \\
\hline 18 & 2 & 7 & 7.5 & 28 & $24.27 \pm 5.02$ & $90.58 \pm 16.56$ & $17.69 \pm 4.68$ & $132.54 \pm 21.69$ \\
\hline 19 & 2 & 14 & 10 & 28 & $37.07 \pm 7.49$ & $137.04 \pm 21.97$ & $13.27 \pm 9.38$ & $183.22 \pm 28.27$ \\
\hline 20 & 2 & 14 & 5 & 34 & $0.29 \pm 0.07$ & $0.54 \pm 0.27$ & $0.44 \pm 0.07$ & $1.17 \pm 0.36$ \\
\hline 21 & 4 & 28 & 5 & 28 & $271.79 \pm 9.00$ & $176.82 \pm 27.10$ & $5.44 \pm 1.21$ & $454.05 \pm 20.15$ \\
\hline 22 & 4 & 14 & 10 & 34 & $0.65 \pm 0.1$ & $0.93 \pm 0.41$ & $0.65 \pm 0.37$ & $2.26 \pm 0.82$ \\
\hline 23 & 1 & 21 & 7.5 & 31 & $3.97 \pm 0.22$ & $8.31 \pm 0.02$ & $3.59 \pm 0.58$ & $15.87 \pm 9.47$ \\
\hline 24 & 2 & 28 & 5 & 28 & $173.64 \pm 22.51$ & $54.87 \pm 31.63$ & $3.02 \pm 1.32$ & $231.54 \pm 17.52$ \\
\hline 25 & 3 & 7 & 7.5 & 31 & $0.35 \pm 0.18$ & $0.47 \pm 0.12$ & $0.52 \pm 0.15$ & $1.34 \pm 0.32$ \\
\hline 26 & 4 & 28 & 10 & 34 & $1.53 \pm 0.80$ & $13.31 \pm 1.04$ & $2.26 \pm 0.40$ & $10.72 \pm 8.05$ \\
\hline 27 & 4 & 14 & 5 & 34 & $0.53 \pm 0.12$ & $0.91 \pm 0.20$ & $2.03 \pm 0.27$ & $8.57 \pm 1.99$ \\
\hline 28 & 2 & 28 & 10 & 34 & $0.29 \pm 0.22$ & $0.11 \pm 0.02$ & $0.63 \pm 0.61$ & $1.89 \pm 0.94$ \\
\hline
\end{tabular}

Each lovastatin value recorded is a mean value from three samples \pm standard deviation (S.D); BE, CE and CH are respectively broth extracts, cell extracts obtained from ethyl acetate, and cell extracts obtain from hexane

TABLE 3. Analysis of variance and regression for lovastatin production

\begin{tabular}{lccccccc}
\hline Source & $\mathrm{SS}$ & $\mathrm{df}$ & $\mathrm{MS}$ & $\mathrm{F}$ & $\mathrm{P}>\mathrm{F}$ & $\mathrm{R}^{2}$ & Adjusted R $^{2}$ \\
\hline Regression & 936485 & 14 & 66891.8 & 14.86 & $<0.0001$ & 0.974 & 0.878 \\
Residual & 58513.6 & 13 & 4501.0 & & & & \\
Total & 994999 & 27 & & & & & \\
\hline
\end{tabular}

$\mathrm{SS}$ is sum of squares; $\mathrm{df}$ is degree of freedom; MS is mean square

be explained by this model. Moreover, the $\mathrm{R}^{2}$ of 0.974 is in reasonable agreement with the adjusted $\mathrm{R}^{2}$ of 0.878 , which confirms the reliability of this model, since the higher the adjusted $\mathrm{R}^{2}$ than 0.75 , the stronger the indication that this model can be acceptable.

The regression coefficients of the model for the lovastatin yield are shown in Table 4 . The results showed that the highest coefficient value was that of the PDB concentration which had the greatest linear effect on the yield. However, the P value of this term was higher than 0.05 indicating the coefficient term to be not significant.
The significance of the regression coefficients of each term can be checked by reference to their P values, which, if less than $0.05(p<0.05)$, indicate that coefficient term to be significant: The smaller the magnitude of $\mathrm{P}$, the more significant the corresponding coefficient (Pansuriya \& Singhal 2010). A comparison of the $P$ values obtained by each term of the regression in Table 4 shows that temperature $(p<0.0000067)$ had the largest effect on lovastatin yield and was a significant linear term, while the interaction between temperature and temperature was a significant quadratic term $(p<0.00001)$. The PDB 
concentration was also a significant linear term $(p<0.021)$ and the interaction between the PDB concentration and the temperature was also significant $(p<0.00855)$. Consequently, it can be concluded that temperature exerted a significant effect on lovastatin production. This may be due to the fact that increasing the temperature leads to poor heat dissipation and a reduction in the oxygen level, thereby inhibiting the growth of microorganisms (Mouafi et al. 2016), which is in agreement with Negishi et al. (1986) and Munir et al. (2018), who found that increasing the temperature to $35^{\circ} \mathrm{C}$ inhibited lovastatin production because the metabolic processes of denaturing enzymes and other proteins were retarded.

The maximum lovastatin yield was $686.72 \pm 66.71$ $\mathrm{mg} / \mathrm{L}$ with a PDB concentration of $3 \times$, a cultivation period of 21 days, a medium to flask volume ratio of 7.5, and a temperature of $25^{\circ} \mathrm{C}$ (Table 2). Juzlov et al. (1996) considered the optimal temperature of $25^{\circ} \mathrm{C}$ observed in this study to be the best incubation temperature for high lovastatin production. Moreover, most of the lovastatin yield was detected in cells extracted with EtOAc (CE) rather than in the broth extracts (BE). This result is not in accordance with the results of cultivation using submerged fermentation, in which most of the lovastatin was found in the broth extracts (Kamath et al. 2015; Mulder et al. 2015). The separation of mycelial film from broth is also easier than that of spherical pellets from broth leading to easier extraction of the lovastatin. The static liquid system was thus viable for lovastatin production.

The RSM plots of the significant parameters for lovastatin production are shown in Figure 2. The optimum values of the four parameters of PDB concentration, time, medium to flask volume ratio and temperature obtained from the maximum point of the model were calculated to be $5 \times$ PDB, 14 days, 2.5 and $25^{\circ} \mathrm{C}$, respectively. The model predicted a maximum response of a yield of $1304.68 \mathrm{mg} / \mathrm{L}$ of lovastatin at this point. The calculated optimum parameters were validated by cultivation under those conditions, which yielded $360.83 \pm 8.47 \mathrm{mg} / \mathrm{L}$ lovastatin. This yield was very much lower than the maximum predicted by the model, which was most likely to have been the result of the cultivation time of 14 days. Under these conditions, 14 days may not be sufficient for secondary metabolism of the polyketide pathway to occur. This result was confirmed by analysis of the total sugar in the medium at the end of cultivation. Using the phenolsulfuric method in accordance with Dubois et al. (1956), the analysis determined glucose contents of 201.21, 84.24 and $9.09 \mathrm{mg} / \mathrm{mL}$ at cultivation times of 0,14 and 21 days, respectively. Following these results, a cultivation period of 21 days was selected for further testing. The outcome of cultivation for 21 days was an increased lovastatin yield of $1315.69 \pm 241.69 \mathrm{mg} / \mathrm{L}$, which was very close to the response predicted by the model $(1233.50 \mathrm{mg} / \mathrm{L})$. Thus, the four optimum parameters were determined as $5 \times$ PDB concentration, 21 days cultivation time, 2.5 medium to flask volume ratio and $25^{\circ} \mathrm{C}$. The use of RSM as an optimization technique has enabled the prediction of a maximum response in a number of previous studies, but in the field of cell cultivation, it is also necessary to consider the cell metabolism as well.

A comparison of the lovastatin production from different Aspergillus species grown on different media is quite difficult and it is not a simple matter to determine which species is the best producer. However, the lovastatin yield obtained from A. sclerotiorum PSU-RSPG 178 in this

TABLE 4. Regression coefficient from the central composite design experiment for lovastatin yield

\begin{tabular}{|c|c|c|c|c|c|}
\hline & Model parameter & Coefficient & $\begin{array}{c}\text { Standard } \\
\text { Error }\end{array}$ & $\mathrm{t}$ value & P value \\
\hline $\mathrm{b}_{0}$ & Constant & 12059.7 & 1818.6 & 6.631 & 0.000016 \\
\hline $\mathrm{b}_{1}$ & PDB con & 533.97 & 205.04 & 2.604 & 0.02183 \\
\hline $\mathrm{b}_{2}$ & Time & -42.12 & 29.29 & -1.438 & 0.174 \\
\hline $\mathrm{b}_{3}$ & Medium to flask ratio & -144.87 & 82.02 & -1.766 & 0.101 \\
\hline $\mathrm{b}_{4}$ & Temp & -713.49 & 98.82 & -7.220 & 0.0000067 \\
\hline $\mathrm{b}_{5}$ & PDB con $\times$ PDB con & 11.69 & 13.69 & 0.853 & 0.409 \\
\hline $\mathrm{b}_{6}$ & Time $\times$ Time & 0.253 & 0.279 & 0.906 & 0.382 \\
\hline $\mathrm{b}_{7}$ & Medium to flask volume ratio $\times$ Medium to flask volume ratio & 1.607 & 2.191 & 0.733 & 0.476 \\
\hline $\mathrm{b}_{8}$ & Temp $\times$ Temp & 10.55 & 1.522 & 6.936 & 0.00001 \\
\hline$b_{9}$ & PDB con $\times$ Time & -1.296 & 2.396 & -0.541 & 0.598 \\
\hline $\mathrm{b}_{10}$ & PDB con $\times$ Medium to flask ratio & -0.801 & 6.709 & -0.119 & 0.907 \\
\hline$b_{11}$ & PDB con $\times$ Temp & -17.30 & 5.591 & -3.094 & 0.00855 \\
\hline$b_{12}$ & Time $\times$ Medium to flask ratio & -0.819 & 0.958 & -0.855 & 0.408 \\
\hline$b_{13}$ & Time $\times$ Temp & 1.269 & 0.799 & 1.588 & 0.136 \\
\hline $\mathrm{b}_{14}$ & Medium to flask ratio $\times$ Temp & 4.268 & 2.236 & 1.909 & 0.07863 \\
\hline
\end{tabular}

$\mathrm{PDB}$ con is PDB concentration (X PDB); and Temp is temperature $\left({ }^{\circ} \mathrm{C}\right)$ 
study is compared to the yields from other Aspergillus species cultured on different media in Table 5; and Table 5 can be used as a guideline when considering the production of lovastatin from different sources. It should be noted that A. sclerotiorm PSU-RSPG 178 in this study produced $1315.69 \pm 241.69 \mathrm{mg} / \mathrm{L}$ of lovastatin, which exceeded that of A. terreus MIM A1 $(256.00 \mathrm{mg} / \mathrm{L})$ at the same temperature of $25^{\circ} \mathrm{C}$ and cultivation time of 21 days. Moreover, this study of the cultivation of $A$. sclerotiorum PSU-RSPG 178 for the production of lovastatin used only PDB while other studies of other Aspergillus species have used more complex media. This result indicates that the cultivation of $A$. sclerotiorum PSU-RSPG 178 has advantages over the cultivation of other species for lovastatin production.

\section{CONCLUSION}

Using RSM, we efficiently identified the optimum conditions for lovastatin production from $A$. sclerotiorum PSU-RSPG 178 using a mycelial plug inoculum under static liquid cultivation and PDB as the carbon source. The lovastatin yield of $1315.69 \pm 241.69 \mathrm{mg} / \mathrm{L}$ was achieved with the following optimized culture conditions: $5 \times$ PDB concentration, 21 days cultivation time, 2.5 medium to flask volume ratio and temperature of $25^{\circ} \mathrm{C}$. This result suggests that $A$. sclerotiorum PSU-RSPG 178 and static liquid cultivation are an effective strain and cultivation system for lovastatin production. The static liquid cultivation is not only successfully employed to cultivate plants but was also

TABLE 5. Lovastatin obtained from other Aspergillus species

\begin{tabular}{|c|c|c|c|c|}
\hline Aspergillus species & Medium & $\begin{array}{l}\text { Cultivation } \\
\text { condition }\end{array}$ & $\begin{array}{l}\text { Lovastatin } \\
(\mathrm{mg} / \mathrm{L})\end{array}$ & Ref \\
\hline $\begin{array}{l}\text { sclerotiorum PSU-RSPG } \\
178\end{array}$ & $\begin{array}{l}\text { PDB }(5 \times) \text { consists of } \\
200 \times 5 \mathrm{~g} / \mathrm{L} \text { potato, } \\
20 \times 5 \mathrm{~g} / \mathrm{L} \text { dextrose }\end{array}$ & $\begin{array}{l}\text { Temp } 25^{\circ} \mathrm{C} \\
\text { Time } 21 \text { days }\end{array}$ & 1315.69 & This work \\
\hline A.terreus NIM A 1 & $\begin{array}{l}70 \mathrm{~g} / \mathrm{L} \text { glycerol, } \\
8 \mathrm{~g} / \mathrm{L} \mathrm{peptone}, \\
1 \mathrm{~g} / \mathrm{L} \mathrm{MgSO}_{4} \cdot 7 \mathrm{H}_{2} \mathrm{O} \\
30 \mathrm{~g} / \mathrm{L} \mathrm{glucose} \\
30 \mathrm{~g} / \mathrm{L} \mathrm{g} \text { whole or defatted soybean flour }\end{array}$ & $\begin{array}{l}\text { Temp } 25^{\circ} \mathrm{C} \\
\text { Time } 10-15 \text { days }\end{array}$ & 256 & $\begin{array}{l}\text { Manzoni et al. } \\
\text { (1998) }\end{array}$ \\
\hline A.terreus & $\begin{array}{l}50 \mathrm{~g} / \mathrm{L} \text { glucose, } \\
20 \mathrm{~g} / \mathrm{L} \text { yeast extract, } \\
30 \mathrm{~g} / \mathrm{L} \text { tomato paste } \\
20 \mathrm{~g} / \mathrm{L} \text { oat meal, } \\
10 \mathrm{~g} / \mathrm{L} \text { sodium acetate, } \\
5 \mathrm{~g} / \mathrm{L} \text { ammonium sulfate, } \\
2 \mathrm{~g} / \mathrm{L} \text { potassium, dihydrogen phosphate, } \\
10 \mathrm{~g} / \mathrm{L} \mathrm{mL} \text { trace element } \\
(\mathrm{pH} 7.0)\end{array}$ & $\begin{array}{l}\text { Temp } 28^{\circ} \mathrm{C} \\
\text { Time } 7 \text { days }\end{array}$ & 55.00 & Samiee et al. (2003) \\
\hline $\begin{array}{l}\text { A.terreus } \\
\text { ATCC } 20542\end{array}$ & $\begin{array}{l}5 \mathrm{~g} / \mathrm{L} \text { corn steep liquor, (CSL), } \\
5 \mathrm{~g} / \mathrm{L} \text { yeast extract }(\mathrm{YE}) \\
5 \mathrm{~g} / \mathrm{L} \text { soybean meal, } \\
15 \mathrm{~g} / \mathrm{L} \text { glucose, } \\
70 \mathrm{~g} / \mathrm{L} \text { lactose, } \\
10 \mathrm{~mL} / \mathrm{L} \text { a trace element solution, } \\
(\mathrm{pH} 6.5)\end{array}$ & $\begin{array}{l}\text { Temp } 28^{\circ} \mathrm{C} \\
\text { Time } 10 \text { days }\end{array}$ & 873.00 & Lai et al. (2007) \\
\hline A.terreus PM3 & $\begin{array}{l}60 \mathrm{~g} / \mathrm{L} \text { lactose, } \\
25 \mathrm{~g} / \mathrm{L} \text { soybean meal, } \\
2 \mathrm{~g} / \mathrm{L} \mathrm{KH}_{2} \mathrm{PO}_{4}, \\
1 \mathrm{~g} / \mathrm{L} \mathrm{K} \mathrm{K}_{2} \mathrm{HPO}_{4}, \\
0.5 \mathrm{~g} / \mathrm{L} \mathrm{MgSO}_{4} .7 \mathrm{H}_{2} \mathrm{O}, \\
1 \mathrm{~g} / \mathrm{L} \mathrm{FeSO}_{4} .4 \mathrm{H}_{2} \mathrm{O}, \\
0.5 \mathrm{~g} / \mathrm{L} \mathrm{NaNO}_{3}, \\
0.5 \mathrm{~g} / \mathrm{L} \mathrm{MnSO}_{4} .7 \mathrm{H}_{2} \mathrm{O}\end{array}$ & $\begin{array}{l}\text { Temp } 28^{\circ} \mathrm{C} \\
\text { Time } 10 \text { days }\end{array}$ & 240.00 & Patil et al. (2011) \\
\hline $\begin{array}{l}\text { Aspergillus terreus PU- } \\
\text { PCSIR-1 }\end{array}$ & $\begin{array}{l}40 \mathrm{~g} / \mathrm{L} \text { lactose } \\
24 \mathrm{~g} / \mathrm{L} \text { peptonized milk, } \\
25 \mathrm{~g} / \mathrm{L} \text { glucose } \% \text {, } \\
12.5 \mathrm{~g} / \mathrm{L} \text { monosodium glutamate, } \\
2.5 \mathrm{~g} / \mathrm{L} \text { yeast extract } \\
3.2 \mathrm{~g} / \mathrm{L} \text { linoleic acid; } \\
(\mathrm{pH}: 7.4)\end{array}$ & $\begin{array}{l}\text { Temp } 28^{\circ} \mathrm{C} \\
\text { Time } 14 \text { days }\end{array}$ & 198.90 & Azeem et al. (2018) \\
\hline
\end{tabular}



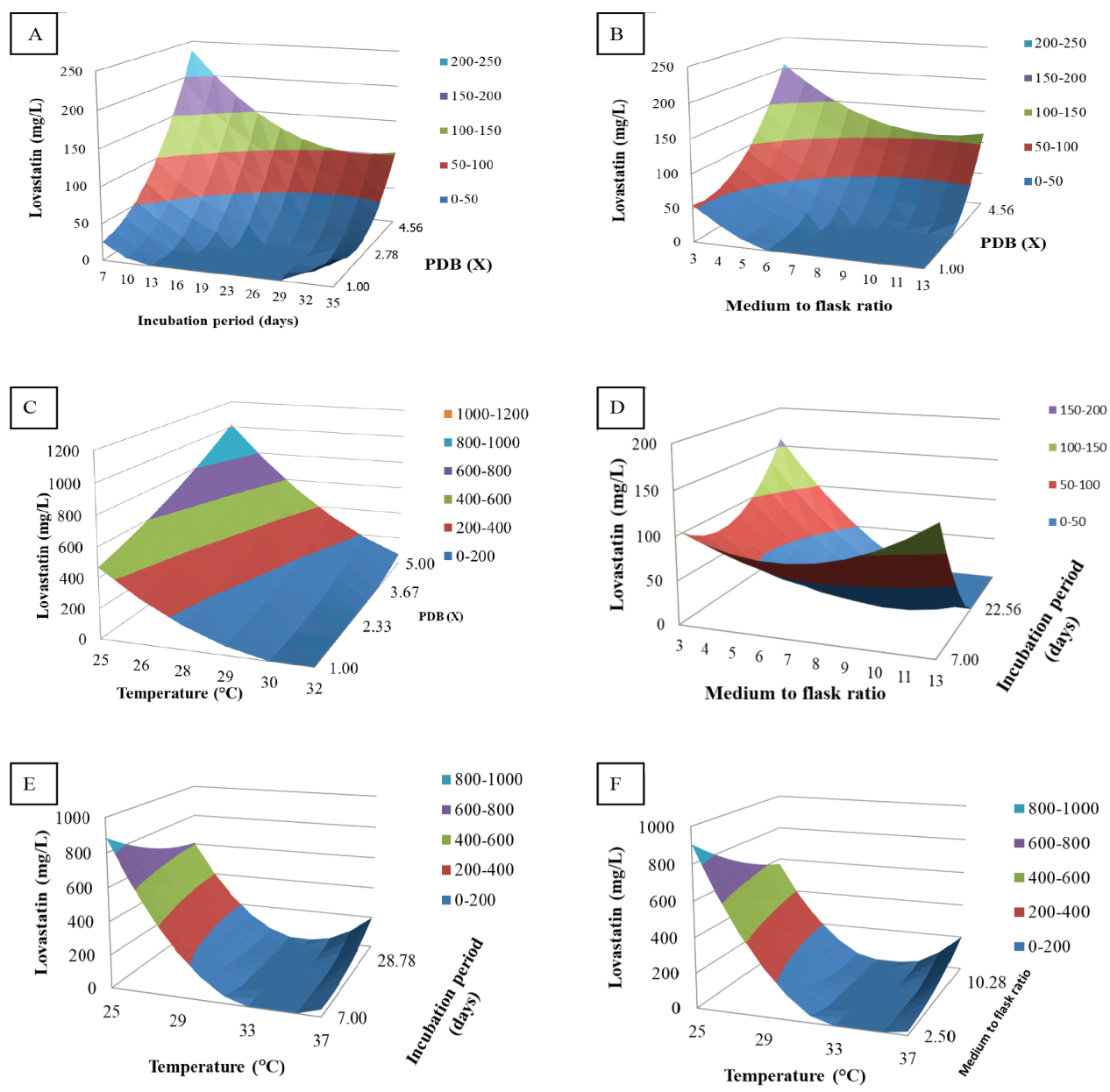

FIGURE 2. Response surface plot showing relative effects of different fermentation parameters on lovastatin production by A. sclerotiorum PSU-RSPG 178

in this study successfully applied to culture $A$. sclerotiorum to produce lovastatin. The use of RSM could be promoted as an optimization technique and logically should contribute to reducing the number of experiments necessary.

\section{ACKNOWLEDGEMENTS}

The authors gratefully acknowledge the NSTDA Chair Professor grant of the Crown Property Bureau and the National Science and Technology Development Agency to Professor Dr. Vatcharin Rukachaisirikul. We also thank the Department of Molecular Biotechnology and Bioinformatics, Faculty of Science, Prince of Songkla University and Center for Genomics and Bioinformatics Research, Faculty of Science, Prince of Songkla University, Hat Yai, Songkhla, Thailand.

\section{REFERENCES}

Atlı, B., Yamaç, M., Yıldız, Z. \& Isikhuemhen, O.S. 2016. Statistical optimization of lovastatin production by Omphalotus olearius (DC.) singer in submerged fermentation. Preparative Biochemistry \& Biotechnology 46: 254-260.

Azeem, M., Saleem, Y., Hussain, Z., Zahoor, S. \& Javed, M.M. 2018. Optimization of culture conditions for the production of lovastatin by Aspergillus terreus in submerged fermentation. Pharmaceutical Chemistry Journal 52(3): 284-289.

Daengrot, C., Rukachaisirikul, V., Tansakul, C., Thongpanchang, T., Phongpaichit, S., Bowornwiriyapan, K. \& Sakayaroj, J. 2015. Eremophilane sesquiterpenes and diphenyl thioethers from the soil fungus Penicillium copticola PSU-RSPG138. Journal of Natural Products 78: 615-622.

Dikshit, R. \& Tallapragada, P. 2015. Bio-synthesis and screening of nutrients for lovastatin by Monascus sp. under solid-state fermentation. Journal of Food Science and Technology 52: 6679-6686.

Douglas, G.C. 1984. Propagation of eight cultivars of Rhododendron in vitro using agar-solidified and liquid media and direct rooting of shoots in vivo. Scientia Horticulturae 24: 337-347.

Dubois, M., Gilles, K., Hamilton, J., Rebers, P.A. \& Smith, F. 1956. Calorimetric method for determination of sugars and related substances. Analytical Chemistry 28: 350-356.

Ibrahim, D., Weloosamy, H. \& Lim, S.H. 2015. Effect of agitation speed on the morphology of Aspergillus niger HFD5A-1 hyphae and its pectinase production in submerged fermentation. World Journal of Biological Chemistry 6: 265-271.

Jia, Z., Zhang, X., Zhao, Y. \& Cao, X. 2009. Effects of divalent metal cations on lovastatin biosynthesis from Aspergillus terreus in chemically defined medium. World Journal of Microbiology and Biotechnology 25: 1235-1241. 
Juzlov, P., Martinkova, L. \& Kren, V. 1996. Secondary metabolites of the fungus Monascus. Journal of Industrial Microbiology 16: 163-170.

Kamath, P.V., Dwarakanath, B.S., Chaudhary, A. \& Janakiraman, S. 2015. Optimization of culture conditions for maximal lovastatin production by Aspergillus terreus (KM017963) under solid state fermentation. HAYATI Journal of Biosciences 22: 174-180.

Kim, E., Hahn, E., Murthy, H. \& Paek, K.Y. 2003. High frequency of shoot multiplication and bulblet formation of garlic in liquid cultures. Plant Cell, Tissue and Organ Culture 73: 231-236.

Lai, L.S., Hung, C.S. \& Lo, C.C. 2007. Effects of lactose and glucose on production of itaconic acid and lovastatin by Aspergillus terreus ATCC 20542. Journal of Bioscience and Bioengineering 104: 9-13.

Lai, L.S.T., Tsai, T.H., Wang, T.C. \& Cheng, T.Y. 2005. The influence of culturing environments on lovastatin production by Aspergillus terreus in submerged cultures. Enzyme and Microbial Technology 36: 737-748.

López, J.L.C., Pérez, J.M.S., Sevilla, J.M.F., Fernández, F.G.A., Grima, E.M. \& Chisti, Y. 2003. Production of lovastatin by Aspergillus terreus: Effects of the $\mathrm{C}: \mathrm{N}$ ratio and the principal nutrients on growth and metabolite production. Enzyme and Microbial Technology 33: 270-277.

Manzoni, M., Rollini, M., Bergomi, S. \& Cavazzoni. 1998. Production and purification of statins from Aspergillus terreus strains. Biotechnology Technology 12(7): 529-532.

Marcin, B. \& Marta, P. 2011. Lovastatin and (+)-geodin formation by Aspergillus terreus ATCC 20542 in a batch culture with the simultaneous use of lactose and glycerol as carbon sources. Engineering in Life Sciences 11: 272-282.

Mihos, C.G., Pineda, A.M. \& Santana, O. 2014. Cardiovascular effects of statins, beyond lipid-lowering properties. Pharmacological Research 88: 12-19.

Mouafi, F.E., Ibrahim, G.S. \& Elsoud, M. 2016. Optimization of lovastatin production from Aspergillus fumigatus. Journal of Genetic Engineering and Biotechnology 14: 253-259.

Mulder, K.C., Mulinari, F., Franco, O.L., Soares, M.S., Magalhães, B.S. \& Parachin, N.S. 2015. Lovastatin production: From molecular basis to industrial process optimization. Biotechnology Advances 33: 648-665.

Mukhtar, H., Ijaz, S.S. \& Ikram-ul, H. 2014. Upstream and downstream processing of lovastatin by Aspergillus terreus. Cell Biochemistry and Biophysics 70: 309-320.

Munir, N., Asghar, M., Murtaza, M.A., Akhter, N., Rasool, G., Shah, S.M.A., Tahir, I.M., Khan, F.S., Riaz, M., Sultana, S., Rashid, A., Akhlaq, M. \& Akram, M. 2018. Enhanced production of Lovastatin by filamentous fungi through solid state fermentation. Pakistan Journal of Pharmaceutical Sciences 31 (4): 1583-1589.

Negishi, S., Haung, Z.C., Hasumi, K. \& Murakawa, S. 1986. Endo a productivity of onacolin $\mathrm{K}$ (mevinolin) in the genus Monascus. Journal of Fermentation and Bioengineering 64: 509-512.

Pansuriya, R.C. \& Singhal, R.S. 2010. Response surface methodology for optimization of production of lovastatin by solid state fermentation. Brazilian Journal of Microbiology 41: 164-172.

Patil, R.H., Krishnanb, P. \& Maheshwarib, V.L. 2011. Production of Lovastatin by wild strains of Aspergillus terreus. Natural Product Communications 6: 183-186.
Phainuphong, P., Rukachaisirikul, V., Saithong, S., Phongpaichit, S., Bowornwiriyapan, K., Muanprasat, C., Srimaroeng, C., Duangjai, A. \& Sakayaroj, J. 2016. Lovastatin analogues from the soil-derived fungus Aspergillus sclerotiorum PSURSPG178. Journal of Natural Products 79: 1500-1507.

Ruchir, C.P. \& Rekha, S.S. 2009. Supercritical fluid extraction of lovastatin from the wheat bran obtained after solid-state fermentation. Food Technology and Biotechnology 47: 159-165.

Samiee, S.M., Moazami, N., Haghighi, S., Mohseni, F.A., Mirdamadi, S. \& Bakhtiari, M.R. 2003. Screening of lovastatin production by filamentous fungi. Iranian Biomedical Journal 7: 29-33.

Sripalakit, P., Riunkesorn, J. \& Saraphanchotiwitthaya, A. 2011. Utilisation of vegetable oils in the production of lovastatin by Aspergillus terreus ATCC 20542 in submerged cultivation. Maejo International Journal of Science and Technology 5 : 231-240.

Suraiya, S., Kim, J.H., Tak, J.Y., Siddique, M.P., Young, C.J., Kim, J.K. \& Kong, I.S. 2018. Influences of fermentation parameters on lovastatin production by Monascus purpureus using Saccharina japonica as solid fermented substrate. $L W T$ - Food Science and Technology 92: 1-9.

Tsai, W. \& Chu, C. 2008. Static liquid culture of doritaenopsis seedlings. Scientia Horticulturae 43: 206-210.

Wong, M.Y. \& Chu, C.Y. 1995. Effect of medium phase on the growth of rose explants in vitro. Journal of Agriculture and Forestry 44: 71-77.

Zhao, Q., Li, M., Chen, M., Zhou, L., Zhao, L., Hu, R., Yan, R. \& Dai, K. 2016. Lovastatin induces platelet apoptosis. Environmental Toxicology and Pharmacology 42: 69-75.

Zhou, B., Wang, J., Pu, Y., Zhu, M., Liu, S. \& Liang, S. 2009. Optimization of culture medium for yellow pigments production with Monascus anka mutant using response surface methodogy. European Food Research and Technology 228: 895-901.

Sudarat Suwannarat, Jutarut Iewkittayakorn \& Wilaiwan Chotigeat*

Department of Molecular Biotechnology and Bioinformatics

Faculty of Science, Prince of Songkla University

Hat Yai, Songkhla 90112

Thailand

Yaowapa Sukpondma \&Vatcharin Rukachaisirikul

Department of Chemistry, Faculty of Science

Prince of Songkla University

Hat Yai, Songkhla 90112

Thailand

Souwalak Phongpaichit

Department of Microbiology, Faculty of Science

Prince of Songkla University

Hat Yai, Songkhla 90112

Thailand

Wilaiwan Chotigeat*

Center for Genomics and Bioinformatics Research

Faculty of Science, Prince of Songkla University

Hat Yai, Songkhla 90112

Thailand 
*Corresponding author; email: wilaiwan58@hotmail.com

Received: 13 October 2017

Accepted: 5 September 2018 